I.С. Кравчук ${ }^{1}$, В.В. Тараненко ${ }^{2}$, Д.В. Башинський ${ }^{2}$, А.Г. Дмитрієв ${ }^{3}$

${ }^{1}$ Товариство з обмеженою відповідальністю “Науково-виробнича фірма “Адрон”, Київ

${ }^{2}$ Державний науково-дослідний інститут авіаиії, Київ

${ }^{3}$ Харківський національний університет Повітряних Сил ім. І. Кожедуба, Харків

\title{
МЕТОДИЧНИЙ ПІДХІД ДО ВИЗНАЧЕННЯ УМОВ ЗАБЕЗПЕЧЕННЯ НЕУРАЖЕННЯ ЛІТАКА ПРИ БОМБОМЕТАННІ 3 КАБРИРУВАННЯ У ЗОНІ ДІЇ ЗАСОБІВ ПРОТИПОВІТРЯНОЇ ОБОРОНИ
}

Розроблено методичний підхід, щзо дає змогу на основі аналізу тактико-технічних характеристик зенітних ракетних комплексів визначати необхідне горизонтальне віднесення керованих авіаційних бомб та горизонтальну дальність введення літального апарату-носія у маневр, щзо забезпечують неураження літального апарату при виконанні ним бомбометання з кабрирування та протиракетного маневру у зоні дії зенітного ракетного комплексу. Показано, щу поєднання маневру літального апарату для бомбометання 3 кабрирування з протиракетним маневром дає змогу суттєво зменшити дальню межу зони ураження зенітного ракетного комплексу.

Ключові слова: керована авіаційна бомба, літальний апарат, зенітний ракетний комплекс, зенітна керована ракета, бомбометання з кабрирування, горизонтальне віднесення, дальність введення у маневр, наземна изіль, протиракетний маневр.

\section{Вступ}

Постановка проблеми. Одними 3 найбільш поширених та ефективних авіаційних керованих засобів ураження класу “повітря - поверхня" для ураження наземних цілей (НЦ) є керовані (коректовані) авіаційні бомби (КАБ) [1-2]. До найвагоміших недоліків переважної більшості існуючих КАБ відносять обмежені можливості по дальності їх бойового застосування, яка знаходиться у діапазоні 3 12 км при скиданні з висот від 500 до 6000 м. Це означає, що літальні апарати (ЛА) - носії таких КАБ, під час їх бойового застосування завжди будуть знаходитися у зоні ураження сучасних зенітних ракетних комплексів (ЗРК), у тому числі таких ефективних та досить поширених, як мобільний всепогодний комплекс ближньої дії “Тор-М1” [3], та зенітний ракетно-гарматний комплекс (ЗРГК) малого радіусу дії “Панцирь-С1"[4].

Виключення можливості ураження ЛА такими комплексами, під час бойового застосування КАБ, може бути досягнуто за рахунок наступних заходів:

- збільшенням дальності польоту КАБ шляхом підвищення та вдосконалення їх енерго-балістичних характеристик;

- виконанням ЛА під час бойового застосування КАБ маневрів, що забезпечують максимальні дальності польоту КАБ, зокрема виконання бомбометання з кабрирування;

- застосуванням ЛА під час атаки НЦ протиракетного маневру, що призводить до зменшення дальньої межі зони ураження зенітної керованої ракети (ЗКР).
Реалізація першого заходу пов язана з суттєвими вдосконаленнями існуючих КАБ, наприклад, оснащенням їх додатковими аеродинамічними несучими поверхнями, твердопаливними ракетними прискорювачами, тощо. Можливості реалізації другого та третього заходів визначаються тактико-технічними та маневровими характеристиками ЛА - носіїв КАБ.

Одним 3 основних параметрів, що зумовлює вимоги до енерго-балістичних характеристик КАБ, є необхідна максимальна горизонтальна дальність польоту КАБ, під якою розуміють максимальну відстань від проєкції точки скидання КАБ на земну поверхню до НЦ. У теорії авіаційного бомбометання ця дальність має назву “горизонтальне віднесення" [5]. Таким чином, задача обгрунтування раціональних значень величини горизонтального віднесення КАБ, які б забезпечували виключення можливості ураження ЛА засобами ППО ближнього та малого радіусу дії, $є$ актуальною.

Аналіз останніх досліджень і публікацій. Питанням бойового застосування ЛА у зоні дії ЗРК присвячена значна кількість публікацій, наприклад [6-10], але у відомих публікаціях практично не розглядаються питання застосування КАБ у зоні дії засобів ППО ближнього та малого радіусу дії, коли ЛА виконує бомбометання зі складного виду маневру, одночасно виконуючи протиракетний маневр. Не розкритими також є питання обгрунтування раціональних значень величини горизонтального віднесення КАБ, які б забезпечували виключення можливості ураження ЛА засобами ППО ближнього та малого радіусу дії. 
Мета статті - розробка математичного апарату для визначення необхідних значень горизонтального віднесення КАБ та дальності введення ЛА у вертикальний маневр, що забезпечують неураження ЛА, при виконанні ним бомбометання з кабрирування та протиракетного маневру у зоні ураження ЗРК ближнього та малого радіусу дії.

\section{Виклад основного матеріалу}

Розглянемо задачу застосування КАБ для ураження НЦ, що прикривається ЗРК. При цьому, ЛА виконує бомбометання з кабрирування та маневр виходу з атаки у вигляді протиракетного маневру. Для спрощення припустимо, що НЦ та ЗРК знаходяться поруч, і відстанню між ними знехтуємо, а наведення КАБ на НЦ реалізується за допомогою супутникової системи самонаведення [15].

Схема виконання польоту ЛА для застосування КАБ з метою ураження НЦ зображена на рис. 1. Як правило, з метою скритності, наближення ЛА до зони застосування засобів ураження (ділянка траєкторії - $a$ ) виконується на гранично малих висотах $H<200$ м. У точці $B$, коли ЛА спостерігається під кутом $\varepsilon$ відносно місця знаходження ЗРК, ЛА починає маневр у вертикальній площині з заданими швидкістю $V_{\text {ла }}$ та перевантаженням $n_{\text {ла }}$ для застосування КАБ з кабрирування. Скидання КАБ виконується у точці $C$ при досягненні кута кабрирування $\Theta=45^{\circ}$, завдяки чому забезпечується максимальна дальність ііі польоту - максимальне віднесення $A$. Продовжуючи політ у вертикальній площині зі швидкістю $V_{\text {ла }}$ перевантаженням $n_{\text {ла }}$ ЛА виконує протиракетний маневр з наступним виходом з атаки (траєкторії $b$ ). Точка $D$ відповідає мінімальній дальності між ЛА та ЗРК. При входженні ЛА у зону пуску ЗРК, виконується пуск зенітної керованої ракети (ЗКР). Через часовий проміжок $t_{p}$ ЗКР сягає точки $D$, де передбачається зустріч ЗКР з ЛА.

Припустимо, що на ділянці ВС (рис. 1) ЛА виконує маневр з постійними величинами $V_{\text {ла }}$ та $n_{\text {ла }}$, то радіус траєкторії $R$ на цій ділянці вертикального маневру запишеться у вигляді:

$$
R=\frac{V_{л а}^{2}}{n_{л а} \cdot g},
$$

де $g$ - прискорення вільного падіння.

Приймаючи швидкість ЗКР іiі середнім значенням $V_{c e p}$ за час польоту $t_{p}$, враховуючи малість кута $\varepsilon$, використовуючи формулу (1) та схему польоту, що зображена на рис. 1, запишемо вирази для $A$ - віднесення КАБ та $D_{b}$ - дальності входження ЛА у вертикальний маневр:

$$
\begin{gathered}
A=\frac{V_{\text {ла }}^{2}}{n_{л а} \cdot g}(1-\cos \Theta)+V_{c е p} \cdot t_{p} ; \\
D_{в}=\frac{V_{\text {ла }}^{2}}{n_{\text {ла }} \cdot g}+V_{c e p} \cdot t_{p} .
\end{gathered}
$$

Формула (3) може бути застосована для вирішення задачі прицілювання при бойовому застосуванні КАБ зі складних видів маневру у випадку атаки НЦ, що прикривається ЗРК. Неураження керованою ракетою ЛА у точці $D$ можливе тоді, коли потрібне перевантаження $n_{\text {nотр }}$, яке необхідне для надійного ураження цілі, перевищує наявне перевантаження $n_{H}$, яке може створювати ЗКР в околі точки $D$, тобто:

$$
n_{\text {nomp }}>n_{H} \text {. }
$$

Розглянемо закономірності зміни перевантажень $n_{\text {nотp }}$ та $n_{H}$. Потрібне перевантаження $n_{\text {nотp }}$ представимо у вигляді суми [11]:

$$
n_{\text {nотр }}=n_{\kappa}+\Delta n,
$$

де $n_{\kappa}$ - кінематична складова потрібного перевантаження, що зумовлює рух ЗКР по траєкторії, яка визначається методом наведення ракети;

$\Delta n$ - складова потрібного перевантаження, яка зумовлена дією сили ваги ЗКР, ії поздовжніми прискоренням та гальмуванням, а також флуктуаційними (випадковими) складовими команд керування. Для сучасних керованих ракет $\Delta n \approx 2-3$ од. [12].

Найчастіше для наведення ЗКР застосовуються методи телекерування - метод трьох точок та метод половинного спрямлення. Для методу трьох точок потрібне перевантаження ЗКР у точці зустрічі з ЛА має вигляд [9]:

$$
n_{\text {потр }}=n_{\text {ла }}+\frac{2}{g} V_{\text {збл }} \cdot \dot{\phi}_{\text {ла }}+\Delta n,
$$

де $V_{\text {збл }}$ - швидкість зближення ЗКР з ЛА;

$$
\dot{\phi}_{л а}-\text { кутова швидкість лінї візування ЛА від- }
$$
носно пункту наведення ЗКР.

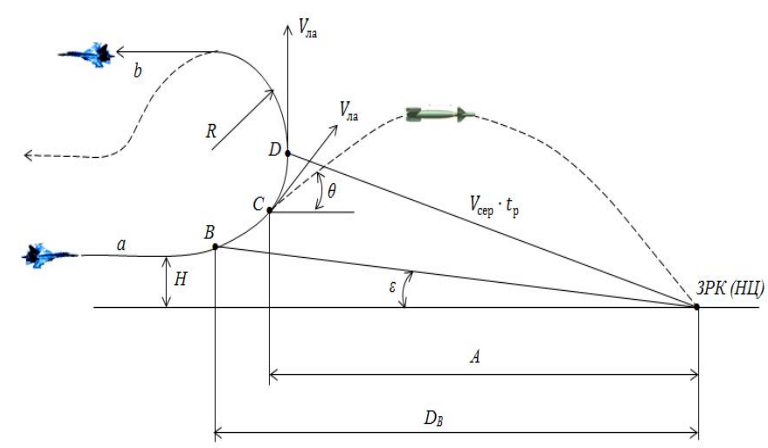

Рис. 1. Схема виконання польоту ЛА для застосування КАБ з метою ураження НЦ Джерело: [1-2]. 
Зокрема, якщо ЛА виконує протиракетний маневр за схемою, що зображена на рис. 1, то в околі точки зустрічі $V_{\text {збл }} \approx V_{c e p}, \dot{\phi}_{л а}=\frac{V_{л а}}{V_{c e p} \cdot t_{p}}$. Тоді (6) перепишеться у такому вигляді:

$$
n_{\text {потр }}=n_{л а}+\frac{2 \cdot V_{\text {ла }}}{g \cdot t_{p}}+\Delta n .
$$

Якщо для наведення ЗКР використовується метод половинного спрямлення, то потрібне $n_{n o m p}$ перевантаження ЗКР у точці іiі зустрічі з ЛА описується за допомогою формули:

$$
n_{\text {потр }}=\frac{1}{g} V_{p} \cdot \dot{\phi}_{\text {ла }}+r_{\text {ла }} \frac{\Delta \ddot{r}}{2 g \cdot \Delta \dot{r}} \dot{\phi}+\Delta n,
$$

де $V_{p}$ - швидкість ЗКР;

$r_{\text {ла }}$ - відстань між пунктом наведення та ЛА;

$\Delta \dot{r}, \Delta \ddot{r}-$ відносні швидкість та прискорення зближення ЗКР та ЛА.

Порівняння виразів (6) і (8) показує, що при методі половинного спрямлення маневр ЛА не впливає на $n_{\text {nотр }}$, але для реалізації цього методу наведення додатково необхідно вимірювати такі параметри, як $\Delta \dot{r}$ та $\Delta \ddot{r}$. При пусках ЗКР на максимальних дальностях та мінімальних висотах польоту ЛА, суттєво зростають помилки вимірювання цих параметрів, що призводить до недопустимого зниження точності наведення ЗКР. Тому, у сучасних ЗРК при пусках ЗКР по маловисотних повітряних цілях, коли на момент пуску $\varepsilon<3^{o}$, застосовують метод трьох точок, а при польоті повітряної цілі на середніх і більших висотах, застосовують як метод трьох точок, так і метод половинного спрямлення [3].

Наявне $n_{\mu}$ перевантаження ЗКР, що входить до виразу (4), являє собою нормальне перевантаження, яке може бути отримане в даних умовах польоту при максимальних відхиленнях кермових поверхонь - рулів. Величина наявного перевантаження $n_{H}$ при аеродинамічному керуванні ЗКР на пасивній ділянці траєкторії польоту описується виразом:

$$
n_{H}=\frac{1}{m \cdot g} c_{y} \frac{\rho \cdot V_{p}^{2}}{2} S
$$

де $m$ - маса ЗКР після вигорання палива ракетного двигуна;

$c_{y}$ - коефіцієнт підйомної сили при максимальному відхиленні рулів;

$\rho$ - щільність повітря на висоті польоту ЗКР;

$S$ - характерна площа.

У виразі (9) змінними параметрами під час польоту ЗКР є величини $c_{y}, \rho$ та $V_{p}$.
На пасивній ділянці траєкторії, внаслідок лобового опору, швидкість $V_{p}$ зменшується від максимального $V_{\text {рмакс }}$ до мінімального $V_{\text {рмін }}$, при цьому, як правило, процес керування ЗКР залишається задовільним при $V_{p}>a$, де а - швидкість звуку. Від швидкості польоту ЗКР залежить коефіцієнт підйомної сили $c_{y}$. Ця залежність для надзвукових швидкостей польоту має вигляд [13]:

$$
c_{y}=b_{1}+\frac{b_{2}}{M}
$$

де $b_{1}, b_{2}$ - коефіцієнти апроксимації;

$$
M=\frac{V_{p}}{a}-\text { число Маха. }
$$

При наведенні ЗКР на ЛА, що виконує маневр у вертикальній площині, висота ії польоту зростає.

Щільність повітря на висотах $H$ від 0 до 5000 м апроксимується залежністю [10]:

$$
\rho=1,23 \cdot \exp \left(-1,02 \cdot 10^{-4} \cdot H\right) .
$$

Аналіз виразів (10) та (11) показує, що у процесі польоту ЗКР параметри $c_{y}$ та $\rho$ змінюються у протилежних напрямках $-c_{y}$ монотонно зростає, а $\rho$ монотонно зменшується. Враховуючи, що на пасивній ділянці траєкторії маса $m$ та характерна площа $S$ ЗКР не змінюються, можна прийняти, що $k=\frac{c_{y} \cdot \rho \cdot S}{2 \cdot m \cdot g} \approx$ const, тоді вираз (9) перепишеться у такому вигляді:

$$
n_{H}=k \cdot V_{p}^{2},
$$

тобто, основним фактором, що визначає величину $n_{\mu} \in$ квадрат швидкості $V_{p}^{2}$ польоту ЗКР.

Якщо для ЗКР відомі максимальні значення швидкості $V_{\text {рмакс }}$ та наявного перевантаження $n_{\text {нмакс }}$, то з використанням виразу (12) можна визначити $n_{\mu}$ для будь якого значення $V_{p}$ за формулою:

$$
n_{\mu}=n_{\text {нмакс }} \frac{V_{p}^{2}}{V_{\text {рмакс }}^{2}}
$$

Однією з основних балістичних характеристик ЗКР є залежність ії швидкості $V_{p}$ від часу польоту $t_{p}$, тому, згідно з (13), наявне перевантаження $n_{\mu}$ ЗКР також залежить від часу польоту $t_{p}$ ракети.

Зазначене ілюструється наступним.

У табл. 1 наведені основні характеристики мобільного всепогодного ЗРК ближньої дії “Тор-М1" [3] та ЗРГК малого радіусу дії “Панцирь-С1"[4]. 
Таблиця 1

Основні характеристики комплексів “Тор-М1” та "Панцирь-С1"

\begin{tabular}{|c|c|c|}
\hline Характеристики & $\begin{array}{c}\text { ЗРК } \\
\text { "Тop-M1" }\end{array}$ & $\begin{array}{c}\text { ЗРГК } \\
\text { "Панцирь-С1" }\end{array}$ \\
\hline \multicolumn{3}{|l|}{ Межі зони } \\
\hline \multicolumn{3}{|l|}{ ураження, км } \\
\hline \multicolumn{3}{|l|}{ По дальності } \\
\hline По висоті & $1-12$ & $1,2-20$ \\
\hline По курсовому & $0,01-6$ & $0,05-15$ \\
\hline \multirow{2}{*}{\multicolumn{3}{|c|}{$\begin{array}{l}\text { параметру } \\
\text { Час реакції }\end{array}$}} \\
\hline & & \\
\hline \multirow{2}{*}{\multicolumn{3}{|c|}{$\begin{array}{l}\text { комплексу, с } \\
\text { Максимальна } \\
\text { швидкість ЗКР, }\end{array}$}} \\
\hline & & \\
\hline $\begin{array}{l}\text { швидкість ЗКР, } \\
\text { м/с }\end{array}$ & 850 & 1300 \\
\hline $\begin{array}{l}\text { Макс. наявне пе- } \\
\text { ревантаження, од. }\end{array}$ & 16 & 32 \\
\hline $\begin{array}{l}\text { Середня швид- } \\
\text { кість ЗКР при }\end{array}$ & & \\
\hline $\begin{array}{l}\text { польоті на макс. } \\
\text { дальність, м/с }\end{array}$ & 640 & 760 \\
\hline
\end{tabular}

Джерело: [3-4].

На рис. 2-3 зображені графіки залежностей $V_{p}\left(t_{p}\right)$ керованих ракет 9M331 та 57Е6-Е комплексів “Тор-М1” [3]: та “Панцирь-C1" [14], відповідно.

Ці залежності відносяться до балістичних характеристик ЗКР і вони є відомими. На цих рисунках зображені також графіки наявних перевантажень $n_{H}\left(t_{p}\right)$, отримані з використанням (13) на основі залежностей $V_{p}\left(t_{p}\right)$ та даних табл. 1 .

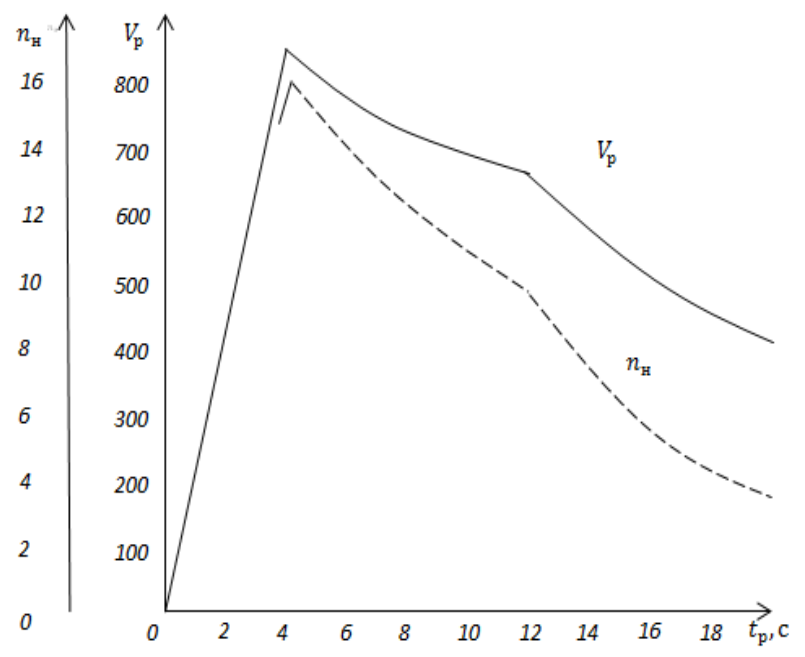

Рис. 2. Залежності $V_{p}\left(t_{p}\right)$ та $n_{H}\left(t_{p}\right)$ для ЗКР 9М331

Джерело: розроблено авторами за даними [3-4].
На рис. 3 зображено графік залежностей $V_{p}\left(t_{p}\right)$ та $n_{H}\left(t_{p}\right)$ керованої ракети 57Е6-Е.

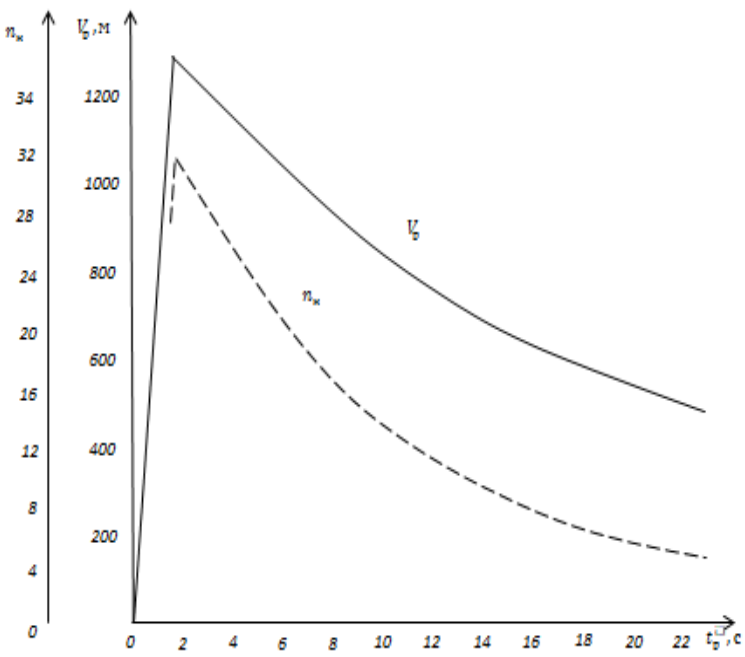

Рис. 3. Залежності $V_{p}\left(t_{p}\right)$ та $n_{H}\left(t_{p}\right)$ ЗКР 57Е6-Е Джерело: розроблено авторами за даними [3-4].

Дані графіків $n_{H}\left(t_{p}\right)$, які наведені на рис. 2, рис. 3 , свідчать проте, що залежності $n_{\mu}\left(t_{p}\right)$, так само, як і $V_{p}\left(t_{p}\right)$ суттєво залежать від часу польоту ракети $t_{p}$.

Повертаючись до нерівності (4), яка зумовлює неураження ЛА зенітною ракетою, приходимо до висновку, що як потрібне перевантаження $n_{\text {nотр }}$ так і наявне перевантаження $n_{\mu}$ в околі точки зустрічі ЗКР та ЛА, залежать від одного і того ж параметру $-t_{p}$, тому нерівність (4) має трансцендентний характер.

Для розв'язання трансцендентної нерівності можуть застосовуватися різні математичні методи, зокрема метод ітерацій та графічний метод.

Скористаємося графічним методом розв'язання нерівності (4), як більш наглядним. Для цього необхідно в одній системі координат побудувати графіки залежності наявного $n_{H}\left(t_{p}\right)$ та потрібного $n_{\text {nотр }}\left(t_{p}\right)$ перевантажень від часу польоту ракети $t_{p}$ (рис. 4).

При цьому, в залежності від параметрів польо-

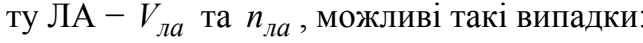

- $n_{\text {nотр }}>n_{H}$ протягом всього часу керованого польоту ЗКР (крива 1). Такий випадок може реалізуватися при виконанні ЛА енергійного протиракет- 
ного маневру з максимально можливим перевантаженням. У цьому разі ураження ЛА неможливе;

- $n_{\text {nотр }}<n_{H}$ протягом всього часу керованого польоту ЗКР (крива 2).

У цьому випадку ЛА може бути ураженим у будь якій точці зони ураження ЗРК. Цей випадок $є$ характерним для польоту ЛА без виконання протиракетного маневру.

- криві $n_{\text {nотр }}\left(t_{p}\right)$ і $n_{H}\left(t_{p}\right)$ перетинаються при деякому значенні $t_{p}$ (крива 3 ). Цей випадок характерний при виконанні ЛА протиракетного маневру з обмеженим перевантаженням, зумовленим, наприклад, бойовим навантаженням. Точка перетину графіків $n_{\text {nотр }}\left(t_{p}\right)$ і $n_{H}\left(t_{p}\right)$ визначає граничне значення часу польоту ракети $t_{p}^{\prime}$.

Якщо час $t_{p}$ польоту ЗКР буде більшим, ніж граничний $t_{p}^{\prime}$, то ЛА не буде уражений ЗКР. У іншому випадку ЗКР уражає ЛА.

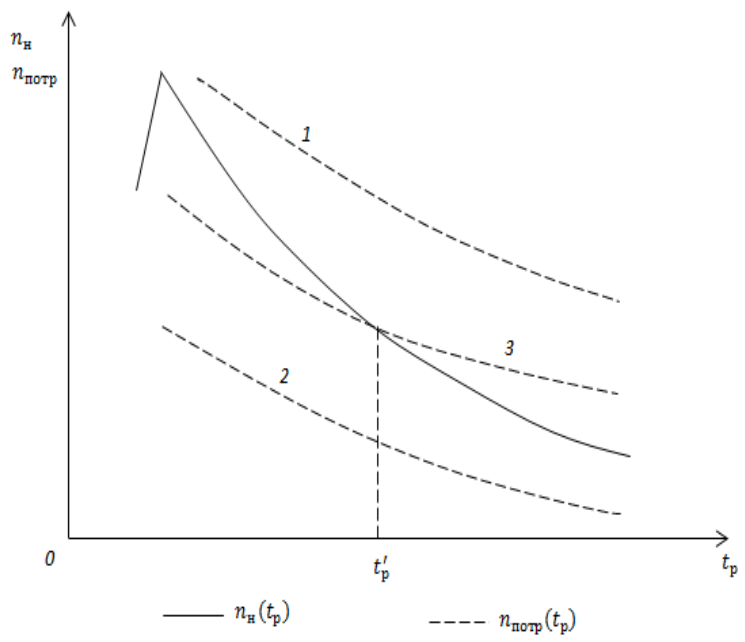

Рис. 4. Графічне розв'язання нерівності

$$
n_{\text {nотр }}\left(t_{p}\right)>n_{H}\left(t_{p}\right)
$$

Джерело: розроблено авторами за даними [3-4].

Бомбометання з кабрирування у типових умовах бойового застосування виконується при швидкостях введення ЛА у маневр $V_{\text {ла }}=200-250 \mathrm{M} / \mathrm{c}$, та перевантаженнях $n_{\text {ла }}=3,5-4,5$.

На рис. 5-6 зображені графіки залежності $n_{H}\left(t_{p}\right)$ для ЗКР 9М331 та 57Е6-Е, відповідно, котрі отримані раніше.

На цих рисунках у тому ж масштабі побудовані графіки залежності $n_{n o m p}\left(t_{p}\right)$, які отримані за до- помогою виразу (7) для швидкості $V_{\text {ла }}=200$ м/с, перевантаження $n_{\text {ла }}=4$ од. і $\Delta n=2$ од.

Аналогічні графічні залежності можуть бути отримані і для інших значень швидкості та перевантаження ЛА.

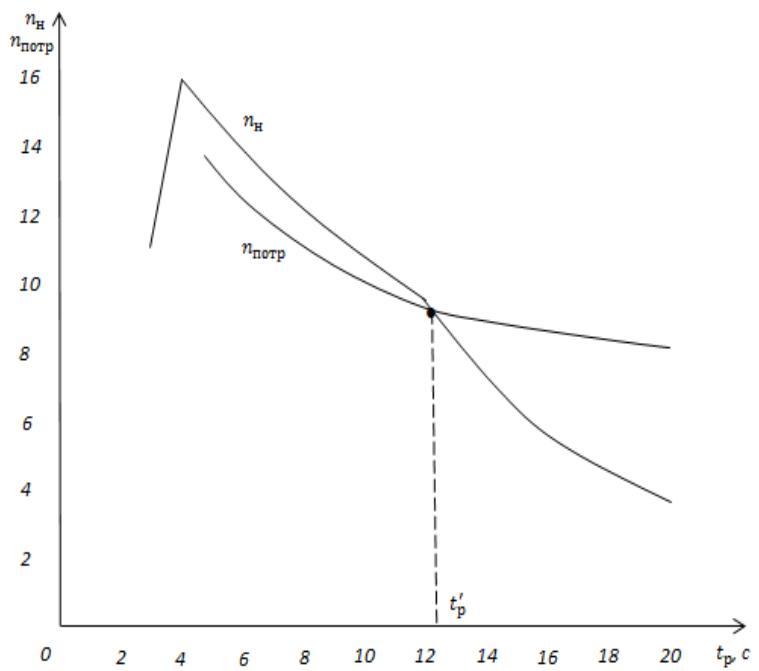

Рис. 5. Залежності $n_{H}\left(t_{p}\right)$ та $n_{\text {nотр }}\left(t_{p}\right)$ ЗКР 9М331 Джерело: розроблено авторами за даними [3-4].

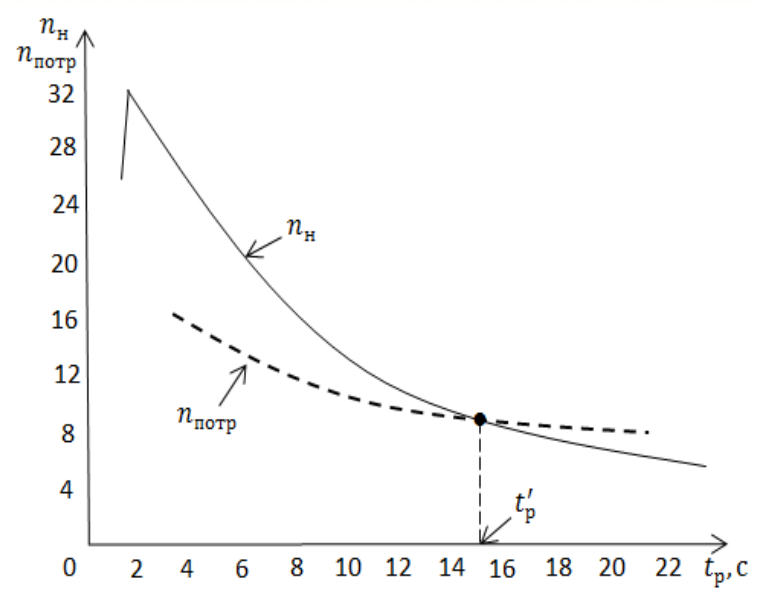

Рис. 6. Залежності $n_{\mu}\left(t_{p}\right)$ та $n_{\text {nотр }}\left(t_{p}\right)$ 3КР 57Е6-Е Джерело: розроблено авторами за даними [3-4].

$$
\text { Точки перетину графіків } n_{H}\left(t_{p}\right) \text { та } n_{n o m p}\left(t_{p}\right)
$$
на цих рисунках визначають граничний час $t_{p}^{\prime}$. $\mathrm{y}$ нашому випадку для ЗКР 9М331 граничний час $t_{p}^{\prime}=12,4 \mathrm{c}$, а для 3КР 57Е6-E $-t_{p}^{\prime}=15 \mathrm{c}$.

Для визначення величини необхідного віднесення $A$ керованої авіабомби та дальності $D_{b}$ входження ЛА у вертикальний маневр, при яких забезпечується неураження ЛА, у формулах (2) та (3) не- 
обхідно прийняти $t_{p}=t_{p}^{\prime}$, а параметри польоту $V_{\text {ла }}$

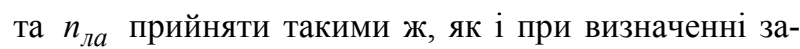
лежності $n_{\text {nотр }}\left(t_{p}\right)$ за формулою (7).

Середня швидкість $V_{c e p}^{\prime}$ ЗКР на інтервалі часу $0-t_{p}^{\prime}$ визначається як:

$$
V_{c e p}^{\prime}=\frac{1}{t_{p}^{\prime}} \int_{0}^{t_{p}^{\prime}} V_{p}\left(t_{p}\right) d t_{p} .
$$

Інтеграл у виразі (14) чисельно дорівнює площі під графіком $V_{p}\left(t_{p}\right)$ на інтервалі часу $0-t_{p}^{\prime}$, тому для визначення $V_{c e p}^{\prime}$ скористаємося графіками, зображеними на рис. 2 і рис. 3 .

Застосувавши (14) до залежностей $V_{p}\left(t_{p}\right)$, отримаємо: для ЗКР 9M331 за час польоту $t_{p}^{\prime}=12,4$ с середня швидкість $V_{c e p}^{\prime}=680 \mathrm{~m} / \mathrm{c}$; для ЗКР 57Е6-Е за час польоту $t_{p}^{\prime}=15$ с середня швидкість $V_{\text {сер }}^{\prime}=840 \mathrm{M} / \mathrm{c}$.

3 використанням отриманих даних, за формулами (2) та (3) тепер можна обчислити величину А горизонтального віднесення КАБ та дальність $D_{b}$ введення ЛА у вертикальний маневр. Зокрема, у нашому випадку, для атаки НЦ, що прикривається ЗРК “Тор-М1”, величина А горизонтального віднесення КАБ, обчислена за формулою (2), повинна бути не меншою, ніж 8,7 км, а дальність $D_{b}$ введення ЛА у вертикальний маневр, обчислена за формулою (3), повинна складати не менше, ніж 9,45 км. У випадку атаки НЦ, що прикривається ЗРГК "Панцирь-С1", А $\geq 12,9$ км, $D_{6} \geq 13,6$ км.

Аналогічно можна визначити параметри А та $D_{в}$ для інших випадків, коли ЛА виконує бомбоме- тання КАБ з кабрирування та протиракетний маневр 3 іншими значеннями швидкості $V_{\text {ла }}$ та перевантаження $n_{л а}$.

$$
\text { Величина } D_{\partial м}=V_{c e p}^{\prime} \cdot t_{p}^{\prime} \text { у виразах (2) і (3) яв- }
$$

ляє собою дальню межу зони ураження ЗРК при обстрілі ЛА, який виконує маневр 3 параметрами $V_{\text {ла }}$ та $n_{\text {ла }}$. Для нашого випадку, коли ЛА виконує маневр у вертикальній площині 3 параметрами $V_{\text {ла }}=200 \mathrm{м} / \mathrm{c}$ та $n_{\text {ла }}=4$ од, дальня межа $D_{\partial м}$ зони ураження ЗРК “Тор-М1” складає 8,4 км у порівнянні з 12 км, згідно з тактико-технічними характеристиками комплексу, при відсутності маневру ЛА. Для ЗРГК “Панцирь-С1" при такому ж маневрі ЛА, величина $D_{\partial м}$ складає 12,6 км, в той час, коли при прямолінійному польоті ЛА величина $D_{\partial м}$ сягає 20 км.

\section{Висновки}

1. Розроблено математичний апарат, що дає змогу на основі тактико-технічних характеристик зенітних ракетних комплексів визначати необхідне горизонтальне віднесення КАБ та горизонтальну дальність введення ЛА у маневр, що забезпечують неураження ЛА при виконанні ним бомбометання 3 кабрирування та протиракетний маневр у зоні дії ЗРК.

2. Поєднання маневру ЛА для бомбометання КАБ $з$ кабрирування $з$ протиракетним маневром дає змогу суттєво зменшити дальню межу зони ураження ЗРК, зокрема, при виконанні вертикального маневру ЛА з постійними швидкістю $V_{\text {ла }}=200 \mathrm{~m} / \mathrm{c}$ та перевантаженням $n_{\text {ла }}=4$ од, дальня межа зони ураження ЗРК “Тор-М1” складає 8,4 км, у порівнянні 3 12 км при відсутності маневру ЛА, а для ЗРПК “Панцирь-С1” ці межі складають 12,6 км та 20 км, відповідно.

\section{Список літератури}

1. Соловей Э.Я. Динамика систем наведения управляемых авиабомб / Э.Я. Соловей, А.В. Храпов; под ред. Е.С. Шахиджанова. - М.: Машиностроение, 2006. -328 с.

2. Семенов С.С. Оценка технического уровня образцов вооружения и военной техники / С.С. Семенов, В.Н. Харчев, А.И. Иоффин. - М.: Радио и связь, 2004. - 552 с.

3. Ельцин С.Н. Зенитный ракетный комплекс “Тор-1М” [Електронний ресурс] / С.Н. Ельцин. - СПб.: БГТУ, 2015. 67 c. - Режим доступу: https://docplayer.ru/53647310-S-n-elcin-zenitnyy-raketnyy-kompleks-tor-m1.html.

4. Офіційний сайт MILITARYARMS.RU. Зенитный ракетно-пушечный комплекс “Панцирь-С1”. Военный обзор. Режим доступу: https://militaryarms.ru/voennaya-texnika/artilleriya/pancir-s1/.

5. Дмитриевский А.А. Внешняя баллистика / А.А. Дмитриевский, Л.Н. Лысенко. - М.: Машиностроение, 2005. - 608 с.

6. Оценка возможности и условий применения высокоскоростной крылатой ракетой противоракетного маневра и радиоэлектронных помех для преодоления зоны потивовоздушной обороны / Б.Н. Ланецкий, В.В. Лукьянчук, И.М. Николаев, Ю.В. Трофименко // Озброєння та військова техніка. - 2018. - № 1(17). - С. 38-45.

7. Арапов О.Л. К вопросу о противоракетном маневре [Електронний ресурс] / О.Л. Арапов, Ю.С. Зуев // Вестник Московского Государственного тенического университета им. Н.Э. Баумана. - 2015. - № 1. - С. 34-46. - Режим доступу: http://vestnikprib/ru/articles/669/669.pdf.

8. Довідник з протиповітряної оборони / А.Я. Торопчин, І.О. Романенко, Ю.Г. Даник та ін. - К.: МО України, 2003. $-368 \mathrm{c}$. 
9. Проектирование зенитных управляемых ракет / И.И. Архангельский, П.П. Афанасьев, Е.Г. Болотов и др. - М.: Изд-во МАИ, 2001. - 732 с.

10. Ярош С.П. Обгрунтування організації зенітного ракетно-артилерійського прикриття угруповань військ з застосуванням міжвидових мобільних вогневих підрозділів ППО / С.П. Ярош, Б.М. Рябуха, Р.А. Соломонович // Наука і техніка Повітряних Сил Збройних Сил України. - 2020. - № 2(39). - С. 77-82. https://doi.org/10.30748/nitps.2020.39.09.

11. Неупокоев Ф.К. Стрельба зенитными ракетами / Ф.К. Неупокоев. - М.: Воениздат, 1991. - 344 с.

12. Основы проектирования ракет класса “воздух-воздух" и авиационных катапультных установок для них / В.А. Нестеров, Э.Е. Пейсах, А.Л. Рейдель и др.; под общ. ред. В.А. Нестерова. - М.: МАИ, 1999. - 792 с.

13. Григорьев В.Г. Авиационные управляемые ракеты / В.Г. Григорьев. - М.: ВВИА им. Н.Е. Жуковского, 1985. $-260 \mathrm{c}$.

14. Фимушкин Ф. ЗРК ближнего действия “Панцирь-С1-0” с оптико-электронной системой наведения / Ф. Фимушкин, В. Слугин // Военный парад. - 2004. - № 3(63). - С. 12-14.

15. Кравчук І.С. Реалізація пропорційного самонаведення коректованої авіаційної бомби за інформацією супутникової системи навігації / І.С. Кравчук, В.В. Тараненко // Наука і техніка Повітряних Сил Збройних Сил України. - 2019. - № 3(36). - C. 73-78. https://doi.org/10.30748/nitps.2019.36.08.

Відомості про авторів:

\author{
Кравчук Ілля Степанович \\ кандидат технічних наук доцент \\ начальник науково-дослідного відділу \\ ТОВ “НВФ “Адрон”, \\ Київ, Україна \\ https://orcid.org/0000-0002-1053-7798
}

\section{Тараненко Віктор Васильович}

кандидат технічних наук

начальник науково-дослідного відділу

Державного науково-дослідного інституту авіації,

Київ, Україна

https://orcid.org/0000-0003-1758-8018

\section{Башинський Дмитро Володимирович}

ад'юнкт

Державного науково-дослідного інституту авіації,

Київ, Україна

https://orcid.org/ 0000-0002-4949-6225

\section{Дмитрісв Андрій Геннадійович}

кандидат технічних наук старший науковий співробітник начальник кафедри

Харківського національного університету

Повітряних Сил ім. І. Кожедуба,

Харків, Україна

https://orcid.org/ 0000-0002-8710-5598
Information about the authors:

\section{Illya Kravchuk}

Candidate of Technical Sciences Associate Professor

Chief of Scientific Research Department

of Research \& Development Company “Adron”,

Kyiv, Ukraine

https://orcid.org/0000-0002-1053-7798

\author{
Victor Taranenko \\ Candidate of Technical Sciences \\ Chief of Scientific Research Department \\ of State Research Institute of Aviation, \\ Kyiv, Ukraine \\ https://orcid.org/0000-0003-1758-8018
}

\author{
Dmytro Bashynskyi \\ Doctoral Student \\ of State Scientific Research Institute of Aviation, \\ Kyiv, Ukraine \\ https://orcid.org/ 0000-0002-4949-6225
}

\author{
Andrii Dmytriiev \\ Candidate of Technical Sciences Senior Research \\ Head of Department \\ of Ivan Kozhedub Kharkiv \\ National Air Force University, \\ Kharkiv, Ukraine \\ https://orcid.org/ 0000-0002-8710-5598
}

\title{
МЕТОДИЧЕСКИЙ ПОДХОД К ОПРЕДЕЛЕНИЮ УСЛОВИЙ ОБЕСПЕЧЕНИЯ НЕПОРАЖЕНИЯ САМОЛЕТА ПРИ ВЫПОЛНЕНИИ ИМ БОМБОМЕТАНИЯ ПО КАБРИРОВАНИЮ В ЗОНЕ ДЕЙСТВИЯ СРЕДСТВ ПРОТИВОВОЗДУШНОЙ ОБОРОНЫ
}

\author{
И.С. Кравчук, В.В. Тараненко, Д.В. Башинский, А.Г. Дмитриев
}

Разработан математический аппарат, дающий возможность на основе тактико-технических характеристик зенитных ракетных комплексов определять необходимый горизонтальный относ управляемых (корректируемых) авиационных бомб и горизонтальную дальность введения летательного аппарата-носителя в маневр, которые обеспечивают непоражение летательного аппарата при выполнении им бомбометания с кабрирования и противоракетного маневра в зоне действия зенитного ракетного комплекса. Показано, что объединение маневра летательного аппарата для бомбометания с кабрирования с противоракетным маневром дает возможность существенно уменьшить дальнюю границу зоны поражения зенитного ракетного комплекса.

Ключевые слова: управляемая авиационная бомба, летательный аппарат, зенитный ракетный комплекс, зенитная управляемая ракета, бомбометание с кабрирования, горизонтальный относ, дальность введения в маневр, наземная цель, противоракетный маневр. 
METHODOLOGICAL APPROACH TO DETERMINING THE CONDITIONS OF PROVIDING AN AIRCRAFT DEFENSE WHEN PERFORMING THE BOMB THROWING IN THE AREA OF AIR DEFENSE MEANS

I. Kravchuk, V. Taranenko, D. Bashinsky, A. Dmytriiev

One of the most common and efficient air-guided weapons of the "air - surface" class for the lethal attack of ground targets are guided (corrected) aircraft bombs. The most important disadvantages of the vast majority of existing guided aircraft bombs are the limited range of their combat use, which is in the range of 3-12 $\mathrm{km}$ when they are airdropped from the altitudes of 500 to $6000 \mathrm{~m}$. This means that the aircrafts will always be in the coverage of antiaircraft threats of the modern anti-aircraft missile systems, in the combat use of such type of bombs. In this case, the exclusion of the possibility of their defeat can be achieved by increasing the flight range of the guided aircraft bombs by rising and improving their energy-ballistic characteristics, performing the aircraft maneuvers during the combat use of the guided aircraft bombs, that provides their best ranges, the using by the aircraft an anti-missile maneuver under the time of attacking of the ground target, which leads to a decrease in the far end of the kill zone of the anti-aircraft guided missile. The use of guided aircraft bombs in the coverage of antiaircraft threats of the close and short radius of action, when the aircraft performs the bombing at a complicated type of maneuver, while performing an anti-missile maneuver simultaneously it isn't being considered in known researches publications. The issues of justification of the rational values of the horizontal range of guided aircraft bombs, which would provide the exclusion of the possibility of hitting the aircraft by antiaircraft threats of the close and short radius of action, are also not disclosed. In the article by the authors were developed a mathematical apparatus that allows on the basis of tactical and technical characteristics of anti-aircraft missile systems to determine the required horizontal range of the guided aircraft bomb and the horizontal range of putting the aircraft in the vertical maneuver, which provide the non-defeat of the aircraft when it performs the toss bombing and the anti-missile maneuver in the coverage antiaircraft threats. The combination of the maneuver of the aircraft for performing the toss bombing of the guided aircraft bomb with an anti-missile maneuver allows significantly reducing the far limit of the zone of destruction of anti-aircraft missile systems.

Keywords: guided (corrected) aircraft bomb, aircraft, anti - aircraft missile system, anti - aircraft guided missile, toss bombing, horizontal reference, range of maneuvering, ground target, anti-missile maneuver. 